\title{
Trust in, trust out: a real cost of sudden and significant financial loss
}

\author{
Aaron Bruhn \\ Research School of Finance, Actuarial Studies and Statistics, College of Business and \\ Economics, The Australian National University, Acton, ACT, Australia
}

\begin{abstract}
This study examines the loss of trust that occurs when individuals suffer from sudden and significant financial loss. We use a qualitative case study to show that individuals lose trust in a range of parties, including financial advisors, banks, credit providers, government and perhaps most damagingly of all, oneself. Such outcomes are concerning as all financial services are based on trust between various parties, and trust is important in making financial decisions. A lack of trust can lead to poorer individual and societal outcomes. It also suggests that trends to financial self-sufficiency have risks, which impact well beyond monetary losses.
\end{abstract}

Key words: Behavioural finance; Financial loss; Financial trauma; Personal finance; Trust

JEL classification: D14, G21, G22, G23, G41, L84

doi: $10.1111 /$ acfi. 12345

\section{Introduction}

Undergoing sudden and significant financial loss can have serious impacts on an individual. This includes emotional reactions such as shock, anger, guilt, distress, confusion, resentment, numbness, disbelief, despair, embarrassment and shame (Iannicola and Parker, 2010; Better Health Channel, 2012). Adverse

The author thanks the supervision of $\mathrm{PhD}$ supervisors in bringing this research to fruition: Associate Professor Timothy Higgins and Professor Michael Martin of the Australian National University, Professor F.D. Foster of the University of Sydney, and Professor Tom Smith of Macquarie University. The author also thanks all research participants for their openness and willingness to share their experiences and time.

Please address correspondence to Aaron Bruhn via email: aaron.bruhn@anu.edu.au 
impacts can be particularly pronounced in the realm of mental well-being and in social aspects such as relationships, cultural and familial roles. These impacts can arise for reasons such as a lack of funds, emotional bankruptcy, vulnerability, and the perceptions and judgements of others. Additional financial stress and emotional stress are apparent when one's home is also impacted, due to moving under duress and a loss of community connection (Bruhn, 2015).

In the context of increasing trends to financial self-sufficiency and a financial landscape that is complex and loaded with choice, insights into financial losses are multifaceted. For example, the baby boomer cohort has a greater expectation than previous generations to be self-funded in retirement, which makes large investment losses more significant (CEPAR, 2012). It is apparent that more could and should be done to understand the field of personal and household finance, with Poterba (2008) highlighting that few studies look at the cost of mistakes in this area.

This study explores how individuals are affected by sudden and significant financial loss, beyond the immediate financial, emotive and social consequences which have been shown previously (Bruhn, 2015). With trust a factor which influences individual financial decision making (Bruhn, 2018), we postulate that a cost of sudden and significant financial loss may also relate to this initially placed trust. Using a qualitative methodology arising from the collapse of Australian financial services company Storm Financial, we indeed find that a significant cost to individuals is a function of trust in the people and institutions they relied upon when making decisions - trust in advisers, trust in institutions, trust in others and trust in oneself.

We first summarise key insights regarding the role of trust in the financial services industry, then give an overview of the adopted case study, data sources and our approach to analysing the data. We then present findings regarding the role and loss of trust in many aspects of life, particularly, but not exclusively in, a financial context.

\section{Trust}

Individuals in the modern world face a complex array of choices with regard to their financial affairs (McKee, 2010; Chardon, 2011). Difficulties in navigating such choices and complexity are exacerbated by levels of financial literacy, which are generally thought to be inadequate (Widdowson and Hailwood, 2007; Iannicola and Parker, 2010). Accordingly, individuals tend to revert to behavioural biases when making decision and resort to heuristics or simple rules of thumb that reduce complex decisions down to more manageable propositions (Bateman et al., 2011a; Sahi et al., 2013; Cheah et al., 2015; Bruhn, 2018).

These issues are especially significant where financial self-sufficiency of individuals is a clear expectation. This is the case in Australia (Joiner et al., 2002), which has only a modest means-tested government age-pension, and a superannuation savings scheme (predominantly defined contribution) where 
investment risks reside with individuals rather than with scheme sponsors such as employers. As such, individuals must engage with the financial services industry to make appropriate fund, investment and insurance choices within superannuation, and/or navigate the complex interactions of entitlement and tax between pensions, superannuation and other investments. Individuals must either seek to understand such things themselves or seek professional advice. Where advice is sought, trust is important because of the relationship between professional service provider and client (Iannicola and Parker, 2010; Nguyen et al., 2017), and where individual understanding is sought, trust is important as a heuristic because it can be a 'short-hand way of making investment decisions' (Smith, 2009, p. 532).

Trust is an essential factor in any functional human relationship, and it is certainly a foundation of the financial services industry (Iannicola and Parker, 2010; Yeates, 2016). Yet only a limited number of papers analyse trust in the financial sector (Jansen et al., 2015). Trust can be enhanced by professional qualifications and credentials (McAlexander and Scammon, 1988; FSA, 2009; Bruhn, 2018), and is also key to whether individuals engage with financial institutions such as banks (Jansen et al., 2015).

The way in which trust is essential in a financial context is multifaceted (Allen et al., 2000; Bruhn, 2013, 2018). First, those who do not understand investments or the market trust professionals because they believe the professional understands it. Second, trust can over-ride regulatory tools such as disclosure, which exist to mitigate adverse impacts of information asymmetry between professional service provider and client (Joiner et al., 2002). Third, the scope of trust bestowed upon financial professionals is significant and may be analogous to the trust placed in other professionals such as medical professionals, implying a 'credibility transfer' due to the perceived association of professionalism and expertise with each (Joiner et al., 2002).

Trust, however, is a fragile commodity. For example, bank managers have seen the largest loss of trust of any group in over thirty years of Roy Morgan surveys (Yeates, 2016); trust in financial institutions can be significantly impacted during times of crisis (Jansen et al., 2015); and trust in the provider of a product or strategy can also be lost when that product or strategy is later seen to be inappropriate (Warren, 2007). Although unethical actions, financial scams and swindles in the financial advice industry are not just recent occurrences (McAlexander and Scammon, 1988), a raft of publicity surrounding various financial disasters has brought these issues even further into the public sphere, particularly because of the GFC (Iannicola and Parker, 2010). In the Australian context, the collapses of Storm Financial, Opes Prime, Westpoint and others generated enormous adverse media coverage, which heightened distrust in the industry (Kliplin, 2010). Consumers' fears of being taken advantage of by advisers with dishonest motives or unprofessional actions are exacerbated by the lack of financial literacy of individuals (Cheah 
et al., 2015), with trust relating to ethical disposition and to the skills and knowledge being offered.

As such, the industry faces challenges because of low levels of trust (McKee, 2010; MacDonald et al., 2013). Consequences of the loss of trust include the retreat of people from future industry engagement, which can further exacerbate losses by being too shy of all risks and potential financial benefits. Yeates (2016) also highlights that any decrease in trust in the banking sector has wider economic implications.

Hence, if the financial services industry is based on a relationship of trust between consumer and service provider, the cost of misplaced trust may be very high. Where trust was relied upon to make financial decisions in the context of much complexity and choice, and those decisions lead to poor outcomes, trust may be a major casualty. Analogous to the idiom for financial modelling: 'garbage in, garbage out' (where model outputs are not robust when input data are not robust, regardless of the model itself); 'trust in, trust out' may suggest that what comes out (loss) is a function of what goes in (trust).

\section{Methodology}

Hypothetical scenarios are often used to draw out behavioural insights of individuals in financial decisions (Joiner et al., 2002; Jansen et al., 2015), although considering real circumstances offers robustness to findings (Weber et al., 2013). We utilise a qualitative case study, of Storm Financial, based on elements of grounded theory, which develops a framework for potential insights after the examination of underlying data, and narrative analysis, which contextualises insights within 'the life and culture' of the times from which a series of observations arose (Patton, 2002, p. 132). Case studies can have particular strengths, when considering a real-world case on its own merits (Stake, 1995; Patton, 2002).

\subsection{Storm Financial}

Storm Financial ('Storm') was an Australian financial planning business that encouraged investors to leverage their homes and other assets to take out positions in equities, primarily via a 100 percent Australian-based index fund. Investor funds were sourced from superannuation and other savings, sales of other assets, new mortgages against the investor's primary residence (even when previously debt-free) and margin loans against the accumulated value of all these sources. House mortgages were provided by major Australian banks, margin loans were usually provided by Macquarie Bank or subsidiaries of the Commonwealth Bank of Australia (CBA) (Ferris, 2011), and investment vehicles for the index funds were usually provided through Challenger or Colonial First State. When equity markets fell during the global financial crisis (GFC), Storm collapsed, generating significant 
financial losses for investors, including many losing their homes and/or total life savings (Washington, 2010a).

The Australian Securities and Investments Commission (ASIC) subsequently banned some Storm advisers due to the provision of inappropriate advice, the making of false and misleading statements, and not understanding, to an appropriate level, the nature and risks of the product(s) they advised on (Lyell and Timms, 2011). A Parliamentary Inquiry (the $\mathrm{PJCI}^{1}$ ) was established, during which two major issues concerning the role of the major banks in Storm's strategy were raised: (i) the processes around the approval of housing and margin loans to individual investors; and (ii) the non-notification of margin calls to investors who had margin loans.

For the first issue, a range of allegations were highlighted. These included false signatures, the overstating of investors' ability to make loan repayments, the over-inflation of property values and multimillion-dollar margin loans without credit checks (Ferris, 2011; Washington, 2011). For the second issue, many investors had no opportunity to rectify their individual margin loan positions when loan-to-value ratios (LVR) were breached, with no communication from either Storm or the margin loan provider regarding the need to make a margin call (Smith, 2009; Ferris, 2011). This was controversial as many investors may have been able to pay the margin call had they been notified.

Many allegations were made that the CBA and its margin-lending subsidiary, Colonial Geared Investments (CGI), were the responsible parties who failed to give investors this opportunity (Sexton, 2012). The CBA's view was that Storm had the responsibility to advise on margin calls (O'Shaughnessy, 2009) and that this approach was standard practice and used with other financial groups. Regardless, the investment vehicles were closed by the relevant entities and fund assets were realised at low values, consolidating losses for investors. Hence, critique of the appropriateness of Storm's advice is somewhat spurious to the crux of the matter in the mind of many investors - opportunity was not given to right their positions, despite being entitled to do so.

Various legal actions have occurred since Storm's collapse, including private class actions and compensation or resolution schemes. Of note, ASIC's pursuit of the CBA for compensation on behalf of Storm investors ceased with a second and final compensation settlement in 2012 (CBA, 2012). More recently, the Australian Federal Court ruled that Storm broke the law via the provision of inappropriate financial advice to vulnerable clients (Hamilton-Smith, 2016).

\subsection{Data}

We use interviews, observations, other correspondence, submissions to the PJCI and transcripts of PJCI public hearings as major data sources. After obtaining University ethics approval and contacting the Storm

\footnotetext{
${ }^{1}$ The Parliamentary Joint Committee on Corporations and Financial Services.
} 
Investors Consumer Action Group (SICAG, a group of impacted investors formed after Storm's collapse), we conducted thirteen interviews with investor individuals or couples, as well as two interviews with ex-Storm advisers. All fifteen interviews were electronically recorded and transcribed, checked and then sent to participants for additional checking. We conducted second interviews with twelve of the original thirteen investor individual/couple(s) in 2013, and further interviews with all thirteen investors in 2015. Interviews have various advantages over other approaches to collection of data involving the perspectives of individuals and are used relatively widely in a number of studies relating to financial issues (FSA 2009; Sahi et al., 2013; Foster and Warren, 2016; Butt et al., 2017). Observations at interviews and comments from eight financial advisers and seven additional ex-Storm investors ${ }^{2}$ provided additional data. A summary of the PJCI submissions and public hearings is provided in Tables 1 and 2:

The 168 PJCI submissions from Storm investors are a form of survey of a select group of those interested in the purpose of the PJCI. While not necessarily a representative pool of all relevant parties, the PJCI chair noted that the number of submissions 'is the largest number (this) committee has ever had' (public hearing [4], p. 1).

We use summary statistics by applying a coding process to all 356 public (nonconfidential) submissions. This coding is based on whether a submission displayed a particular feature, for example 'loss of trust in adviser'. We also refer to submission [154] from the consulting firm AEC Group, who in April 2009 surveyed 421 SICAG members and 314 members soon thereafter. Such statistics provide supplementary information as a more convenient and concise alternative to excessive descriptive evidence.

We did not utilise a specialist computer application to manage the large volume of data, preferring instead to read through paper records and highlighting or making notes by hand as required (or Excel when dealing with the 'coding' of submissions). Although there is utility of such computer applications for many researchers including steps around initial analysis (Patton, 2002), we share the perspective of Saldana (2016) who claims 'more control over and ownership of the work' (p. 29), and Marshall and Rossman (2010), who perceive more 'intimate immersion in one's data' with a computerfree approach (p. 217).

\footnotetext{
${ }^{2}$ Correspondence arose from presentations to University colleagues $(2011,2013)$; a US Society of Actuaries conference (2011); an academic, actuarial and regulatory audience at the University of Auckland (2012); MLC financial advisers (2014); and an Actuaries Institute Financial Services Forum (2014). It also arose from feedback on papers published in industry journals early in the research.
} 
Table 1

Breakdown of submissions to the PJCI

\begin{tabular}{lcr}
\hline Type of Submitter & Number of submissions & Number of pages \\
\hline Impacted investors from Storm & 168 & 763 \\
Other investors & 74 & 310 \\
Financial Advisers/Planners & 43 & 486 \\
Other & 71 & 1,320 \\
Confidential & 42 & Not known \\
Total & 398 & 2879 \\
\hline
\end{tabular}

Available at: http://www.aph.gov.au/Parliamentary_Business/Committees/Joint/Corporations_ and_Financial_Services/Completed_inquiries/2008-10/fps/submissions/sublist

\subsection{Developing key themes}

When presenting key insights, we endeavour to be transparent by presenting the perspectives of research participants in their own words. This gives additional context to the reader to agree or otherwise with the interpretation we have made (Patton, 2002; Eisenhardt and Graebner, 2007; Corbin and Strauss, 2008). The explicit arrangement of participant quotes into key themes and findings demonstrates the links made to statements and insights residing in the data itself.

To give assurance that key themes 'actually have some congruence... with the reality of the phenomenon studied' (Anfara et al., 2002, p. 29), a range of procedures are considered relevant (Anfara et al., 2002; Marshall and Rossman, 2010; Stake, 1995). Two that we adopted included member checking and triangulation of data - the latter through written submissions, reports of verbal exchanges in public hearings and interviews. These data sources include a variety of contexts for views to be expressed, which is a useful advantage when dealing with the 'subtle variations in ongoing human experience' (Denzin and Lincoln, 2005, p.21).

\section{Findings}

We detail how an individual's level of trust in various facets of their life has changed due to Storm's collapse. Perhaps the simplest overview of the loss of trust is given by one investor, who in email correspondence (January 2013) stated that 'I have learned not to trust people when it comes to financial circumstances'. The objects of distrust include Storm itself, the wider financial advisory industry, the banking sector, other professionals such as lawyers, government as the ultimate provider of collective protection and provision, and oneself. To provide important context for impacted areas of trust, we first discuss views and perceptions on two key areas of dispute and angst for many 
Table 2

Details of public hearings

\begin{tabular}{llll}
\hline Number and date of hearing & Location & $\begin{array}{l}\text { Length of } \\
\text { transcribed } \\
\text { record (pages) }\end{array}$ & $\begin{array}{l}\text { Number of } \\
\text { parties (people) } \\
\text { appearing before } \\
\text { committee }\end{array}$ \\
\hline [1] 24 June 2009 & Canberra & 50 & $1(5)$ \\
[2] 26 August 2009 & Melbourne & 116 & $8(19)$ \\
[3] 28 August 2009 & Canberra & 89 & $6(18)$ \\
[4] 1 September 2009 & Cairns & 105 & $4(13)$ \\
[5] 2 September 2009 & Townsville & 112 & $6(14)$ \\
[6] 3 September 2009 & Brisbane & 115 & $7(10)$ \\
[7] 4 September 2009 & Sydney & 120 & $7(20)$ \\
[8] 16 September 2009 & Canberra & 58 & $2(8)$ \\
[9] 28 October 2009 & Canberra & 58 & $2(7)$ \\
\hline
\end{tabular}

Available at: http://www.aph.gov.au/Parliamentary_Business/Committees/Joint/Corporations_ and_Financial_Services/Completed_inquiries/2008-10/fps/hearings/index

investors: the provision of loans to investors and the various issues around margin lending and margin calls.

\subsection{Areas of angst}

Three main deficiencies have been acknowledged in the loan approval processes for Storm investors: lending against investment earnings; a lack of suitable pre-approval checks; and a general 'massaging' of applications. Issues of lending solely on investment earnings were raised by SICAG, ex-employees of Storm and some interviewees. One interviewee stated that the bank 'gave me this loan and they were just taking the repayments from my investments with Storm, which were all in shares and they shouldn't give loans on shares'.

Some investors commented on the lack of physical inspection of a home prior to loan approval, and others highlighted that banks should have taken more prudent steps.

The banks have some responsibility in our demise, as not once did Colonial meet with us or interview us regarding our loans or how we intended-at our age- to repay approximately $\$ 1.6$ million... the (bank) who mortgaged our home to the sum of $\$ 380,000$, never ever contacted us... had they interviewed us (they) would have known that our income shown on the application was more than double what we were getting for our investments. [public hearing [4], pp. 35-36]

As many investors felt that a loan approval was tacit approval of investor involvement, many lay blame with credit providers. Claims of false witnessing of loan applications, false details on income and loan increases occurring without authority were also made. One interviewee claimed that their loan 
documents were 'witnessed by people that we had never met', 'the information on the loan application was wrong' and that they never signed particular loan applications. Submission [276] by SICAG re-iterated most of these concerns, and ASIC observed that normal lending standards were awry 'in some cases', resulting in 'higher risk lending to retail investors and inadequate management of existing loans' (submission [378]). Such shortcomings have been acknowledged by various banks (e.g., ANZ in submission [379], CBA in submission [357] and the Bank of Queensland in public hearing [8], p. 48).

However, just as significant an issue was who should have made the margin calls and when, and why in many cases no margin call occurred. These issues were given much attention across all data sources, with the perspective of exStorm employees in public hearings [4] and [5] and submission [281], Storm's founder in public hearing [6] and the FPA also inferring some responsibility upon credit providers in submission [277]. While investors' perceptions would be influenced by credit providers being a possible source of recompense at the time of the PJCI, there is nevertheless a strong perception that the credit providers were at fault. Various submissions from Storm investors indicate the depth of feeling held (e.g., submissions [91], [129], [207], [211], [269] and [356]), and according to the AEC/SICAG survey, 93 percent of respondents believed that their margin lender should have contacted them for the purposes of making a margin call. Furthermore, 25 percent of respondents had previously experienced a margin call, and of those, 63 percent were advised of this via the bank, 33 percent via Storm and 4 percent through both. An interview excerpt demonstrates where a strong sense of blame is perceived to lie.

We had a negative equity of about $\$ 320,000-\$ 350,000$ on the (margin) loan. We were able to find the funds (but) they sold us down at the worst possible time in the investment cycle without any consultation - in spite of the fact we have a document saying they would provide us with 5 days' notice before taking any action. [interview with Storm investor]

A further concern to investors was not just the lack of a margin call, but also the nature of contact from credit provider(s) immediately following the closing of investment funds. For example, one investor highlighted that written advice they received was in the name of another investor, of the wrong amount, and did not account for an offsetting credit (public hearing [4], p. 35). Such contact strengthened impressions as to where operational failures occurred.

The CBA's belief was that Storm simply 'struggled to deal with the exceedingly volatile times the market was experiencing' (public hearing [7], $\mathrm{p}$. 85 ) and that 'while we advised Storm of margin calls, Storm did not action these with its clients on a timely basis' (submission [357]). Macquarie Bank gave similar views in public hearing [9] (p.3). Furthermore, not all investors laid responsibility with credit providers, with one interviewee stating that Storm had duty of care as equity values fell and 'should have been monitoring it more 
closely'. Others similarly highlighted Storm's lack of contingency plans in the event of a falling equity market (submission [287]).

Regardless of where responsibility truly lies, 80 percent of AEC/SICAG survey respondents did not receive a margin call prior to the sell down of the index fund, with many having LVRs exceeding 100 percent. This is despite having agreements that they would be contacted directly if required, with this assurance a major factor in pursuing Storm's strategy. The resulting emotional stress and frustration were conveyed by one interviewee.

I had a margin loan with the (bank). Storm didn't have that margin loan, I had it. I had contractual obligations that weren't met. They just sold me up without any notice whatsoever. No buffer call, no margin call, nothing... for the sake of a 30cent phone call, you couldn't be bothered to contact me, even though you knew that the Storm Financial product was geared in such a way that if I didn't correct it, I would be catastrophically destroyed. [interview with Storm investor]

Many investors are therefore left with a huge sense of loss and distrust, suggesting that what is lost is partly a function of what was relied upon when entering the strategy. If indeed trust in Storm, advisers, banks and credit providers, and one's own judgement were key factors in choosing Storm, then a loss of trust in each of these could be expected to arise.

\subsection{Summary of findings}

Table 3, modified from Anfara et al. (2002) and Neck (2013), summarises the main concerning trust themes to emerge from the data and gives a brief quotation to illustrate why that theme was significant.

\subsubsection{Loss of trust in Storm strategy and personnel}

Trust in Storm - as a company, a group of individuals and a strategy - was a significant factor in deciding to invest. Therefore, postcollapse, the most obvious target for distrust is Storm. This was clearly prominent in the minds of investors making a submission to the PJCI, with 118 of 168 submissions making adverse observations about Storm. Negative comment was also offered in 27 of 76 submissions from financial planners, financial services organisations/associations and other individuals.

Reasons for distrust concerned the investment strategy, issues associated with communication of risk and the apparent greed associated with high commission structures (Bruhn and Miller, 2014). Of note is that the repeated assurances given to investors about investment safeguards in place, to build up trust, have now given way to less trust than would otherwise be the case.

We often raised questions about risk but were always assured the risks were minimal and well managed, to let them do the worrying and leave the risk management to them. During the decline in the markets we again expressed our 
Table 3

Summary of Findings

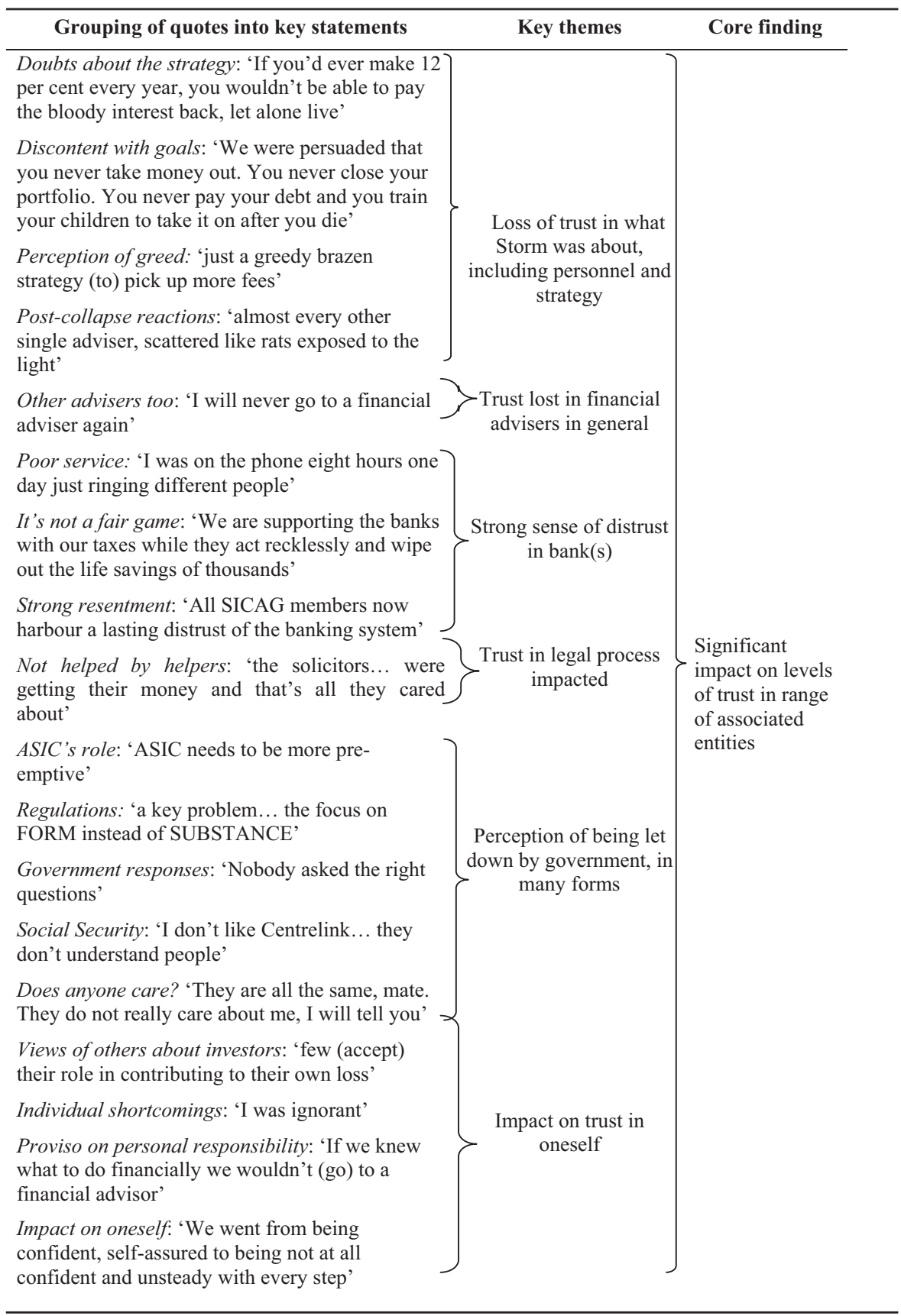


concern about our investments but were assured that the strategies in place would always protect us. [public hearing [4], p. 48]

\subsubsection{Loss of trust in the financial advice industry}

It is perhaps inevitable that a collapse on the scale of Storm would have wider ramifications in terms of trust (e.g., submission [251]; public hearing [7], p. 27). Indeed, it is reasonable to assume that membership of a body like the FPA would increase trust in a prospective adviser/client relationship, and such credentials were a factor for investors when considering Storm's strategy. But, consequently, the FPA also finds itself in a challenging position of dealing with consumer trust, as attested by one investor:

Storm Financial may as well have been a member of the local $\mathrm{RSL}^{3}$ club for all the FPA endorsement means... (professionals tell us to) look for financial planners who have a good track record, who are members of FPA and have ASIC endorsement. Well we ticked all those boxes and still ended up losing everythin0067. [submission 220]

Although the FPA defended its dealings with Storm in submission [277], others questioned its role in not taking a more pro-active approach prior to Storm's demise (e.g., submission [154]). Of 168 submissions by Storm investors, 12 indicated some discontent with the FPA's role and two (out of 43) submissions from financial planners also expressed some disappointment.

In terms of broader industry perceptions, 40 of 74 submissions from nonStorm investors indicated distrust or negative commentary. Interviews allowed us to dig into broader issues of trust some years after the event, and we find some differences between investors. Some adamantly declare a loss of trust in all advisers and highlighted the money factor that they believed motivated advisers.

These blokes aren't doing it for nothing. They're looking after their own backsides, their own interest, whether they be a used car salesman, whether they be a real estate agent, whether they be a financial adviser... it's number one-first. . the more money they can get out of you, the bigger and fatter their wallets are going to be. [interview with Storm investor]

For other interviewees, there was nothing specific that they could convey, and it was simply a case of now not accepting or trusting anyone's suggestions about any financial matter.

A downside therefore, for the industry is that such 'distrust transfer' can swamp the good outcomes and advice that many could receive (e.g., see public hearing [2], p. 13; and public hearing [7], p. 111). One financial adviser emailed us with their frustration that the 'aberrative behaviour' of one group 'could

\footnotetext{
${ }^{3}$ The Returned and Services League of Australia, which supports veterans, servicemen and servicewomen.
} 
have such a big impact on the entire profession/industry'. This naturally contrasts with the views of many Storm investors, and re-engaging those specific investors is no small challenge. One adviser from Queensland described her own experience of dealing with Storm investors after the collapse.

I am part of what is the collateral damage of Storm... a lot of planners in Cairns have been supporting a lot of ex-Storm clients... we are doing a lot of work to try to get them back on the track, but I do not think I will ever get-well, hopefully, I will have their trust, but I suspect it is going to take a very, very long time. [public hearing [4], p. 93]

Clearly, winning back trust is not straightforward - another financial planner noted that 'many people don't seek advice, not because they don't want it, but because they don't trust it, and therefore, they don't value it' (submission [342]). An industry CEO stated that 'transparency and trust will be the battleground of the next decade in financial services' (public hearing [2], p. 12), specifically with respect to 'the root cause around trust, which (concerns) the client being at the centre of the decisions that are made' (p.7).

However, some investors have re-engaged with advisers again, inferring that professional distrust is not a universal outcome. One interviewee re-engaged with a financial adviser due to a strong professional relationship, and another did so with a stronger sense of their own risk tolerance.

\subsubsection{Loss of trust in banks}

Despite the obvious distrust of Storm and the wider financial advice industry, it is noteworthy that disenchantment, anger and distrust of banks and credit providers are even more strongly evidenced. Of the 168 submissions by Storm investors, 127 referred detrimentally to the role of banks and credit providers more than the 118 submissions were adverse towards Storm. Additionally, 45 of 74 submissions from non-Storm investors similarly highlighted adverse perceptions of banks and credit providers, more than the 40 who had criticisms of advisers. This speaks to a severe loss of trust in what should otherwise be a cornerstone institution in one's financial affairs.

This distrust arose for many reasons, fuelled by perceptions of close associations between the banks and Storm, and the issues around loans and margin calls. Distrust was also exacerbated by a sense of injustice given taxpayer assistance to the major banks during the GFC, which gave additional protection for the recipient banks' liabilities ${ }^{4}$ (e.g., see submissions [211] and [276], and public hearing [6]).

The postcollapse treatment of investors also had a major impact on trust, with perceptions of unreasonable service and a lack of care. Frustrations have

\footnotetext{
${ }^{4}$ For details of the Australian Government Guarantee Scheme for Large Deposits and Wholesale Funding, see http://www.guaranteescheme.gov.au.
} 
arisen when trying to settle some outstanding affairs, with one interviewed couple stating that they 'couldn't get to talk to anybody and that was the really, really frustrating part... nobody knew anything about it'. This couple had extended issues in dealing with their bank, showing documentation of 21 phone calls over a 10-week period which culminated with an officer from their bank's complaints division not finding any record of the previous twenty phone calls. Given the importance of information and clarity to investors at this time, this caused 'immeasurable distress'. Such service accentuates perceptions that customers are seen merely as agents of convenient economic value, rather than real people with real needs. This part of the overall experience has been particularly troublesome.

The way we were treated by the (bank); that's where our house was loaned, was absolutely appalling. They would not even talk to us. I said to them, you know, 'What's going to happen? Where do we stand? Are we going to lose our house?' They said, 'Well, if you don't pay your margin money, you'll lose your house' and I said you know, 'Where are we going to live?' Couldn't give a s-, was the reply. [interview with Storm investor]

The above investor also stated that they did not know whether Storm or the banks were to blame for the overall collapse, with similar sentiments more widely expressed (e.g., public hearing [6], p. 62; and submission [230]). This highlights that postcollapse treatment is a significant influence on trust, not just the allocation of responsibility or fault. Indeed, where investors perceive unfair or unprofessional responses, a severe distrust results. This is significant given that customer loyalty can be enhanced by addressing and fixing mistakes, rather than never making mistakes (Burley, 2012).

For many, the story of Storm is more about the role of the banking sector, rather than Storm itself. The result of this is not a favourable one for any party involved, with SICAG highlighting their members' 'lasting distrust of the banking system' (submission [276]). Most interviewees highlighted similar sentiment, including the consequences of such distrust:

Husband: Well, there's a residual affect for us. You give us all our money back now, I can tell you one of the big problems we're going to have is what do we do with it?

Wife: Who do you trust?

Husband: I mean I wouldn't put it anywhere near a bank again. [interview with Storm investor]

\subsubsection{Loss of trust in lawyers}

Various lawyers have been involved in resolution schemes and class actions since Storm's collapse. CBA's resolution schemes involved more than 2,000 
clients (Trenwith, 2010) and other banks also offered compensation schemes, on a smaller scale (Washington, 2010c). There was initially hope that pending resolution scheme(s) would deliver appropriate restitution for investors (e.g., submission [306]), but views have changed over time with substantial angst regarding various aspects of such scheme(s) (Washington, 2010b). Such angst includes the process involved in seeking resolution and the outcomes received.

One investor, themselves a barrister, stated that both the process and agenda of the scheme did not seem to run in the interests of investors (Goodridge, 2010), with the time given for individuals to consider compensation offers far too limited in the light of the financial stress involved. Early concerns about the process were also raised by SICAG members in public hearing [6] (p. 80). For interviewees, such early concerns grew over time:

I didn't feel they were acting in our best interest. At first, I did, but after a while I realised no... they gave up too quick... at first it was like, yeah, we'll support you, we'll get you what you deserve... then they just caved in real quick and I'm thinking - I've become very suspicious then; whose side are you really on? [interview with Storm investor]

What this again leads to is a lack of trust in a professional service that is foundational for modern life. In ten interviews, discussion about the legal profession was either critical, guarded or resigned.

\subsubsection{Loss of trust in government}

Perceptions of government arose not just from actions of elected representatives, but also from perceptions of the regulatory setting and regulator, interaction with Centrelink (who are responsible for assessment and payment of a range of social security benefits), overall political interest and comment on Storm's collapse, and the process and outcomes of the PJCI. These formulate an impression of 'government', and with multiple influences involved, quite different perceptions can arise. We consider each relevant arm of government in turn.

Regulation. Outside of strong capital-based protection for insurers, banks and superannuation providers, the Australian system for financial services and provision is generally based on a belief that lightly regulated, market-led competition delivers the most effective results for individuals, businesses and the overall economy. Davis (2009) highlights contrasting views around regulation arising from the GFC, with some seeing excessive faith being placed in such light-touch regulation, whereas others see the primary failure being in its implementation.

Interviews gave rise to little discussion concerning the general regulatory environment, and just 13 of 168 submissions from Storm investors discussed this in concerned or critical terms. This is unsurprising, with investors focussed on 
Storm, banks or more tangible government contexts to them such as ASIC and the PJCI itself. However, 15 out of 64 submissions from financial planners and financial services organisations/associations did comment in adverse terms about regulation, with the main concerns about the focus and limits of regulation.

In terms of regulatory focus, many criticised the emphasis on 'form' versus that of 'substance', or equivalently the process of giving advice versus the quality of advice (e.g., submission [135]). Furthermore,

Storm Financial produced large Statements of Advice, which had the required FORM... (but) the focus on FORM rather than SUBSTANCE has allowed many to create the appearance of quality where in fact there was none. So, the focus on FORM contributes to the consumer being misled and deceived. [submission 154]

In terms of regulatory limits, the shortcomings of disclosure as a regulatory tool was highlighted by many. Disclosure has various goals, including making clear any conflicts arising from remuneration arrangements, and to reduce issues of information asymmetry between professionals and less-informed consumers (Bateman et al., 2011b). However, the mechanism of disclosure was questioned, with a financial planning executive stating that Storm's documentation to investors of over 100 pages 'did not help them better understand what they were doing' (public hearing [2], p. 92), and the Treasury similarly stating that 'excessive or complex information can be counterproductive, as it may confuse investors' (submission [388]). Others highlighted that compliance with requirements is not synonymous with quality of advice (public hearing [2], p. 113) and that disclosure of conflicts can even be counterproductive (public hearing [7], p. 98). ASIC itself stated that disclosure may not address information asymmetry, as clients may not be able to perceive the significance of what has been disclosed to them (submission [378]).

Another limitation raised was that regulatory change often lags the pace of market innovation (e.g., public hearing [8], p. 34) and that regulation merely provides a challenge for service providers to work around for the benefit of profit and gain (Davis, 2009; West, 2009). Similarly highlighted is that 'regulation, legislation and banning commissions will not do and cannot do anything' to prevent the sorts of outcomes that occurred with Storm (submission [407]).

Regulator. Closely linked to regulation is the role of the relevant regulator, the Australian Securities and Investments Commission (ASIC). ASIC has oversight of various financial services entities including the advice industry and emphasises the role of licensing, conduct and disclosure. Providing a balanced view on the role and responsibility of ASIC has challenges as negative views tend to predominate publicly, with regulatory bodies often taking the brunt of angst in such situations (e.g., see submission [168]).

As such, frustration exists amongst investors as to what ASIC can and does do, which in investor's minds includes licensing; a knowledge of and therefore 
implicit approval of a business model; ongoing surveillance; the possibility of market intervention to protect consumers; and postevent action. Some 37 of 168 submissions by Storm investors spoke to an ASIC role which they perceived was inadequate, as did 29 of 74 submissions from non-Storm investors, 11 of 43 submissions from financial planners and 20 other submissions.

In terms of licensing, investors gained comfort from Storm having an ASICapproved Australian Financial Services Licence (AFSL) ${ }^{5}$. From this, many investors inferred that 'the investment and the organisation has been vetted by ASIC' (submission [404]) and that 'the regulators would be aware of the kind of advice that Storm were applying to their clients' (public hearing [4], p. 55). The latter investor admitted shortcomings of this perception by adding, 'we were too trusting, it seems'. ASIC itself clarified in public hearings [1] and [8] that an AFSL merely indicates that minimum requirements have been met as part of initial registration and that because of low barriers to entry, the ability to revoke licences is limited. ASIC also highlighted that there may be a mistaken belief that a licence 'is in some way an endorsement of quality' (public hearing [1], p. 70). Nevertheless, many investors did trust in what they thought a licence inferred, and this trust extrapolated to government as a whole (e.g., [submission 220]).

In terms of market surveillance and intervention, one perception is that ASIC could have done more to prevent a collapse. ASIC stated that 'there was no evidence on which ASIC could have and should have taken action to close down Storm' (submission [378]) and highlighted that it 'is not supposed to intervene in the operation of the market... (it) cannot and does not take action merely on the basis of a flawed business model' (public hearing [1], p. 5).

However, the Investment and Financial Services Association (IFSA) argued that oversight could involve pre-emptive action (public hearing [3], p. 51), and West (2009) suggested that 'common sense might have prevailed (as) a model which aggressively pursued the leverage of elderly clients with little or no income was flawed and bound for disaster'. Several interviewees emphasised similar points.

ASIC's subsequent legal pursuit of the major banks and Storm postcollapse has not necessarily inspired confidence or trust, but has potentially only served to accentuate perceptions that ASIC should have acted in advance of the collapse. Consequently, for many investors, the actions of a government regulator reflect on government itself.

Government response via the PJCI. The PJCI made a number of recommendations for the industry, including a ban on up-front and trailing commissions

\footnotetext{
5 Any entity providing a financial service must have an Australian Financial Services Licence (AFSL) - effectively a gatekeeping mechanism to check the competency, integrity and resources of such entities at the time of application.
} 
for a range of financial products, and the introduction of a statutory fiduciary duty for financial advisers to act in the best interests of their clients. ${ }^{6}$ Notably, one stated goal was to promote trust in the advice industry.

Unsurprisingly, there were a range of reactions to these reforms (AFA, 2011). Of surprise was that few interviewees commented on the commission and fiduciary duty aspects of these recommendations - perhaps partially explained by a lack of interest in things that would not provide recompense. Some investors did begrudgingly accept that some effort towards accountability had been made via the PJCI, but views were mixed on its utility in forming a better advice industry.

In terms of the PJCI as a process, there was a general feeling that it provided some benefit as a forum to be heard. However, where the PJCI was seen as a mechanism for personal restitution, views were naturally negative when this turned out not to be the case. This was particularly so for investors who wanted credit providers to be subject to far more scrutiny than they were, especially with respect to issues around margin calls. A typical view was that "nobody asked the right questions... they let the banks off very lightly... (it achieved) nothing of value for the victims' (interview with Storm investor). As such and in line with a growing scepticism of government in general, other views showed a resignation to and perception of bureaucratic process being the order of the day.

I saw a heap of jobs being created for mates because they're going to have a committee for this and a working group for that and another committee for this and I know that's the way politics works. [interview with Storm investor]

Centrelink. Engaging with Centrelink was a necessity for many investors after Storm's collapse, including 25 percent of AEC/SICAG survey respondents. Given that a major motivation to join Storm was the pursuit or consolidation of financial self-sufficiency, a need for social security was difficult to accept. Importantly, investors' experience in this process informed perceptions of the role of government in their lives and given their own difficult circumstances, negative perceptions prevailed.

Care of government. Belief in whether government was concerned with the welfare of impacted individuals was also key to whether government can be trusted or not. One investor could not contain their strong feelings about the matter.

For our politicians to have sat by quietly and pretend that nothing is happening is despicable. I'll never vote for a major political party ever again because I've asked

\footnotetext{
${ }^{6}$ See http://futureofadvice.treasury.gov.au/content/Content.aspx?doc $=$ media_releases. htm.
} 
for their help as an Australian citizen and got nothing. Not even a polite refusal.

Nothing. [interview with Storm investor]

This investor voiced incredulity at why government would not be more concerned with such events, due to the large number of individuals having 'their life savings catastrophically wiped out', with consequent impacts on welfare, pension, health and rental assistance outlays. Another investor highlighted that because government has pushed individuals to seek financial self-sufficiency, which he felt he had then done and seen it collapse, his trust in government was therefore minimal (public hearing [5], p. 109). Furthermore, he has less trust not just in government, but potentially in many avenues of collective care. An unsettling outcome is therefore that investors may become even more isolated and prioritise self-reliance above collective mechanisms of care more than is in their interests to do so.

\subsubsection{Loss of trust in oneself}

Although Storm's collapse has catalysed distrust towards various parties, perhaps the most damaging loss of trust has been in oneself. It may be that the more significant the responsibility taken by the individual, the stronger the impact on trust in oneself. Indeed, 'it's not so much about the pain of making a loss, but rather the pain of being responsible for making the decision' (Van Munster, 2011, p. 29).

The issue of individual responsibility for getting involved with Storm was discussed in some depth in 13 interviews. An ex-Storm adviser highlighted that individuals had opportunities to know exactly what they were getting into, by being required to read and sign every page of the statement of advice. However, a senior lawyer highlighted shortcomings with such views, reflecting earlier discussion regarding the inadequacy of disclosure:

I have had people argue until they are blue in the face that a statement of advice from Storm Financial of 125 pages was perfectly compliant with the law and that, in fact, the consumer had signed every page, thereby rendering it a document that they understood. We both know, firstly, that document probably did not impart the advice that it was supposed to give. Secondly, it certainly did not explain the risks associated with the products and the strategy. Thirdly, it certainly did not have anything to do with the quality of the advice that was imparted through it. [public hearing [2], p. 113]

Reflecting on the above comment, it is evident that although individual investors generally acknowledged personal responsibility, this was tempered somewhat when viewed in context of the responsibilities of others, particularly the trust placed in the adviser and associated institutions (e.g., submissions [21], [165], [285], and [307]).

Discussion of personal responsibility was also linked to an impact on trust in oneself. One investor highlighted their struggle that 'my instincts had failed me 
- even though I had thought about and checked on and researched Storm for 18 months' (submission [320]), and an interviewee highlighted their additional angst: 'it's a self-bashing thing... how could I have been so stupid to have allowed myself to get involved with them?'. As such, dealing with life in general is impacted, as displayed by one interviewed couple whose body language and overall demeanour were very despondent.

Losing trust in one's own financial decision making can extrapolate to trust in others, leaving many with a very real challenge to trust again. Yet, the realisation remains that to have any reasonable basis for life, trust is essential.

I'm not a stupid person but I certainly feel like one now. They hoodwinked me big time. Any lessons to be learnt; yeah, don't be so trusting. Just don't be so trusting. I mean what else can you do? There's nothing you can do about it though, you can't go through life not trusting people. [interview with Storm investor]

\section{Conclusion}

As social beings, humans need trust in themselves, others close to them and wider societal connections to function effectively in the world. Furthermore, because institutions, professions and various collective organisations are needed to assist individuals in navigating life's various uncertainties, trust in such entities is also essential. In particular, the financial system is built on a trust that financial promises entered into will be honoured by all parties including the financial advice sector, various institutions, professions and government. Elements of distrust in government are particularly complex. Many Storm investors presented mixed views on government responses to Storm's collapse, and a confused picture of what regulation means and what regulators do, as reasons to find trust difficult.

The strongest sense of distrust however arises from disenchantment and adverse perceptions of banks and credit providers involved with Storm. Importantly, this lack of trust has arisen as much from events postcollapse as it has from anything else. Many investors also now admit to less trust in their own judgements and ability. In an environment when self-provision for one's financial well-being is strongly encouraged, a loss of trust in not just oneself, but also the environment in which one exists, is concerning. It may well be the case that the cost of events like the GFC is more about 'social capital' rather than more immediate economic impacts (Yeates, 2016).

The case study of Storm highlights that the impact upon individuals who suffer from sudden and significant financial loss can be viewed in the light of the people and institutions individuals relied on when choosing to invest. On the other side now of significant losses, many investors doubt whether their future can operate with the same level of trust as before. 'Trust in, trust out' is perhaps a fitting description of the unfortunate outcome for many. 


\section{References}

Association of Financial Advisers (AFA), 2011, The tides of change, The Australian Journal of Financial Planning 2, 1-11.

Allen, D. E., E. G. McGoun, and G. W. Kester, 2000, A sociological explanation of financial market growth, International Review of Financial Analysis 9, 421-432.

Anfara, V. A., K. M. Brown, and T. L. Mangione, 2002, Qualitative analysis on stage: making the research process more public, Educational Researcher 31, 28-38.

Bateman, H., T. Islam, J. Louviere, S. Satchell, and S. Thorp, 2011a, Retirement investor risk tolerance in tranquil and crisis periods: experimental survey evidence, Journal of Behavioral Finance 12, 201-218.

Bateman, H., C. Eckert, J. Geweke, J. Louviere, S. Satchell, and S. Thorp, 2011b, Financial Competence, Risk Presentation and Retirement Portfolio Preferences, Working paper. (Australian School of Business Research, The University of New South Wales, Sydney, NSW, Australia).

Better Health Channel, 2012, Retrenchment or financial loss. Available at: https:// www.betterhealth.vic.gov.au/health/healthyliving/retrenchment-or-financial-loss.

Bruhn, A., 2013, What Happens When It All Goes Wrong - A Study into the Impacts of Personal Financial Shocks. (The Australian National University, Canberra, Thesis for the degree of Doctor of Philosophy).

Bruhn, A., 2015, Personal and social impacts of significant financial loss, Australian Journal of Management 40, 459-477.

Bruhn, A., 2018, Relying on the heuristic of trust - a case study, Accounting \& Finance (forthcoming).

Bruhn, A., and M. Miller, 2014, Lessons about best interests duty, The Australasian Accounting Business and Finance Journal 8, 23-44.

Burley, R., 2012, Customer Service: 5 Rules for Handling Complaints. Available at: https:// www.inc.com/ron-burley/customer-service-5-rules-for-handling-complaints.html.

Butt, A., M. S. Donald, F. D. Foster, S. Thorp, and G. J. Warren, 2017, Design of mysuper default funds: influences and outcomes, Accounting and Finance 57, 47-85.

Commonwealth Bank of Australia (CBA), 2012, Commonwealth Banks settles Storm Financial litigation with ASIC. Available at: https://www.commbank.com.au/about-us/ news/media-releases/2012/140912-cba-settles-storm-financial-litigation-ASIC.html.

Centre of Excellence in Population Ageing Research (CEPAR), 2012, New research shows the GFC has led to increased depression in seniors. Available at: https:// www.cepar.edu.au/news-events/news/new-research-shows-gfc-has-led-increased-depre ssion-seniors.

Chardon, T., 2011, Weathering the storm: tax as a component of financial capability, Australasian Accounting Business and Finance Journal 5, 53-68.

Cheah, K. K., F. D. Foster, R. Heaney, T. Higgins, B. Oliver, T. O’Neill, and R. Russell, 2015, Discussions on long-term financial choice, Australian Journal of Management 40, 414-434.

Corbin, J., and A. Strauss, 2008, Basics of Qualitative Research: Techniques and Procedures for Developing Grounded Theory, 3rd edn. (Sage Publications, Thousand Oaks, CA).

Davis, K., 2009, Financial regulation after the global financial crisis, Australian Economic Review 42, 453-456.

Denzin, N. K., and Y. S. Lincoln, 2005, The discipline and Practice of Qualitative Research, in: N. K. Denzin, Y. S. Lincoln, eds., The SAGE Handbook of Qualitative Inquiry, Ch. 1, 3rd edn. (Sage Publications, Thousand Oaks, CA).

Eisenhardt, K. M., and M. Graebner, 2007, Theory building from cases: opportunities and challenges, Academy of Management Journal 50, 25-32. 
Ferris, S., 2011, Unlocking the equity in your home, Actuary Australia 7, 16-19.

Foster, F. D., and G. J. Warren, 2016, Interviews with institutional investors: the how and why of active investing, Journal of Behavioral Finance 17, 60-84.

Financial Services Authority (FSA), 2009, Describing advice services and adviser charging. Available at: http://www.fsa.gov.uk/Pages/Library/research/Consumer/in dex.shtml.

Goodridge, R.I., 2010, Letter to the Storm Investors Consumer Action Group (SICAG). Available at: http://www.sicag.info/RIG\%201tr\%20to\%20SICAG\%2017\%203\% 2010.pdf.

Hamilton-Smith, L., 2016, Storm Financial Former Directors Breached Law, Federal Court finds, ABC News (26 August 2016). Available at: http://www.abc.net.au/news/ 2016-08-26/storm-financial-former-directors-breach-law-justice-finds/7790366.

Iannicola, D., and R. Parker, 2010, Barriers to Financial Advice for Non-Affluent Consumers. Available at: https://www.soa.org/research/research-projects/life-insura nce/research-barriers-consumers.aspx.

Jansen, D., R. H. J. Mosch, and C. A. B. van der Cruijsen, 2015, When does the general public lose trust in banks?, Journal of Financial Services Research 48, $127-$ 141.

Joiner, T. A., L. Leveson, and K. Langfield-Smith, 2002, Technical language, advice understandability, and perceptions of expertise and trustworthiness: the case of the financial planner, Australian Journal of Management 27, 25-43.

Kliplin, R., 2010, Back to basics - why people with financial advisers are happier, richer and more purposeful, The Australian Journal of Financial Planning 5, 21-33.

Lyell, K., and P. Timms, 2011, Former Storm Financial Representative Banned, ABC News (25 February 2011). Available at: http://www.abc.net.au/news/2011-02-25/ former-storm-financial-representative-banned/1957234.

MacDonald, B. J., B. Jones, R. J. Morrison, R. L. Brown, and M. Hardy, 2013, Research and reality - a literature review on drawing down retirement savings, North American Actuarial Journal 17, 181-215.

Marshall, C., and G. B. Rossman, 2010, Designing Qualitative Research, 5th edn. (Sage Publications, Thousand Oaks, CA).

McAlexander, J. H., and D. L. Scammon, 1988, Are disclosures sufficient? A micro analysis of impact in the financial services market, Journal of Public Policy \& Marketing Special Issue 7, 185-202.

McKee, A., 2010, Role of Advisers within the Financial Services Market - Lynchpin or Leech?, Paper presented at the Institute of Actuaries of Australia 5th Financial Services Forum, 13-14 May 2010. (Sydney, Australia).

Neck, C., 2013, What are the Drivers That Lead Women to Leave a Senior Role in Finance in Australia? A Mixed Methods StudyThesis for the degree of Doctor of Philosophy. (The University of Queensland).

Nguyen, L., G. Gallery, and C. Newton, 2017, The joint influence of financial risk perception and risk tolerance on individual investment decision-making, Accounting \& Finance (2017), Version of Record online: 5 Sep 2017.

O'Shaughnessy, V., 2009, Storm Financial swept into administration, The Sydney Morning Herald (13 January). Available at: http://www.smh.com.au/business/stormfinancial-swept-into-administration-20090112-7f7u.html.

Patton, M. Q., 2002, Qualitative Research \& Evaluation Methods, 3rd edn. (Sage Publications, Thousand Oaks, CA).

Poterba, J., 2008, Session 2 comments, in: Z. Bodie, D. W. McLeavey, L. B. Siegel, eds., The Future of Life-Cycle Saving and Investing, 2nd edn. (Research Foundation Publications, CFA Institute), 48-54. 
Sahi, S. K., A. P. Arora, and N. Dhameja, 2013, An exploratory inquiry into the psychological biases in financial investment behavior, Journal of Behavioral Finance 14, 94-103.

Saldana, J., 2016, The Coding Manual for Qualitative Researchers. (Sage Publications, London).

Sexton, E., 2012, Pair pin Storm's fall on bank and ASIC failures, Sydney Morning Herald (8 February 2012). Available at: http://www.smh.com.au/business/pair-pinstorms-fall-on-bank-and-asic-failures-20120207-1r587.html.

Smith, D. K., 2009, Regulating investment risk: individuals and the global financial crisis, UNSW Law Journal 32, 514-546.

Stake, R. E., 1995, The Art of Case Study Research. (Sage Publications, Thousand Oaks, CA).

Trenwith, C., 2010, Storm Financial Compensation deal looms, Brisbane Times (12 February 2010). Available at: https://www.brisbanetimes.com.au/business/stormfinancial-compensation-deal-looms-20100212-nvqq.html.

Van Munster, R., 2011, Understanding "Greed and fear" - the key to successful investing", The Australian Journal of Financial Planning 6, 23-31.

Warren, E., 2007, Unsafe at any rate, Democracy: A Journal of Ideas 5, 8-19.

Washington, S., 2010a, Founder may face criminal charges, Sydney Morning Herald (28 May 2010). Available at: http://www.smh.com.au/business/founder-may-face-crimina 1-charges-20100527-whtl.html.

Washington, S., 2010b, Trail of emails charts decline of Stormy romance, Sydney Morning Herald (22 November 2010). Available at: http://www.smh.com.au/busine ss/trail-of-emails-charts-decline-of-stormy-romance-20101121-182lc.html.

Washington, S., 2010c, ANZ follows CBA with Storm victims' resolution plan, Sydney Morning Herald (18 September 2010). Available at: http://local.images.smh.com.au/ business/anz-follows-cba-with-storm-victims-resolution-plan-20100917-15gg3.html.

Washington, S., 2011, Storm investors' accidental legacy, Sydney Morning Herald (9 May 2011). Available at: http://www.smh.com.au/business/storm-investors-accidenta 1-legacy-20110508-1ee73.html.

Weber, M., E. U. Weber, and A. Nosic, 2013, Who takes Risks When and Why: Determinants of Changes in Investor Risk Taking, Review of Finance 17, 847-883.

West, M., 2009, Ripoll does little to stop another Storm, Sydney Morning Herald (25 November 2009). Available at: http://www.smh.com.au/business/ripoll-does-little-tostop-another-storm-20091124-jhc1.html.

Widdowson, D., and K. Hailwood, 2007, Financial literacy and its role in promoting a sound financial system, Reserve Bank of New Zealand Bulletin 70. Available at: http://www.rbnz.govt.nz/research_and_publications/reserve_bank_bulletin/2007/ 2007jun70_2widdowsonhailwood.pdf.

Yeates, C., 2016, How a loss of trust hurts the economy, Sydney Morning Herald (14 June 2016). Available at: http://www.smh.com.au/business/banking-and-finance/howa-loss-of-trust-hurts-the-economy-20160612-gphkui.html. 